\title{
Developing Country Concerns on Multinational Trade: Problems of Kyrgyzstan's Trade Development
}

\author{
Aidai Budaichieva (International Ataturk-Alatoo University, Kyrgyzstan) \\ Kiyalbek Akmoldoev (International Ataturk-Alatoo University, Kyrgyzstan) \\ Jarkyn Junushbaeva (International Ataturk-Alatoo University, Kyrgyzstan)
}

\begin{abstract}
The essence of global economy lies in creation of multilateral trading system. However, in current world practice the multilateralism does not respond to its ideal concept: countries do not get equal gains from multilateral trading system. Dependence on import is the major concern of developing countries within WTO. As other developing countries Kyrgyzstan has a negative trade balance. Yet non-membership appears to be an even less viable option. The aim of this paper is to find out an appropriate trade policy for Kyrgyzstan.
\end{abstract}

JEL Codes: F10, F13

\section{Introduction}

Multilateralism, in the context of global trade, is defined as "an approach to the conduct of international trade based on cooperation, equal rights and obligations, non-discrimination and participation as equals of many countries regardless of their size or share of international trade" ( Dictionary of trade policy terms 2nd ed. 1998, 187). However, countries do not get equal gains from multilateral trading system.

The General Agreement on Tariffs and Trade (GATT) and its successor, the World Trade Organization (WTO), were set up to promote world trade which is based on multilateralism.

Opinions about WTO tent to differ sharply: opponents of globalization see in it a symbol and motor of globalization that has tightly come into for much criticism; for others the WTO is one of the essential building blocks of multilateral and cooperative world order, indeed an instrument of restraining the process of globalization. The widespread and sustained interest in joining it underlines the importance attached by many countries to WTO membership - even though, especially in developing countries liberalization has given way to growing disappointment, and very few such countries are able to sustain in increasingly competitive trading conditions. Yet non-membership appears to be an even less viable option.

As many developing countries Kyrgyzstan is experiencing positive and negative effects from membership in WTO. Kyrgyzstan entered the WTO in 1998. For thirteen years of experience in multilateral trading system Kyrgyzstan had faced such benefits like access to cheaper import, low prices for domestic consumers and comparative advantage to re-export in comparison to other regional trade partners. However, there are also negative effects of WTO membership. Huge flow of import goods had discouraged domestic production; low import tariffs on agricultural products restrain development of agriculture sector. Kyrgyzstan also has trade relationships with non-members of WTO, mainly with regional trade partners such asRussia and Kazakhstan. But creation of the Customs union (CU) between Russia, Kazakhstan and Belarus in 2010 had strong effects on Kyrgyz trade balance. This situation leads to the need to decide whether Kyrgyzstan's economic development and prosperity would be best served by closer integration with the relatively high-tariff system of the CU, which is based on the existing tariff system of Russia, or by continuing the low-tariff, essentially open and free-trade oriented system that it adopted upon WTO accession.

The aim of this paper is to:

- analyze the condition of developing countries in agriculture within WTO

-analyze the impact of WTO membership of Kyrgyzstan on its trade

-to find out whether to enter the CU or stay within WTO membership

As well as other developing WTO member countries Kyrgyzstan's expectations have not been met. The negative trade balance witnesses its consequences: enormous inflow of import prevents from domestic production growth. Moreover, during the accession process to the WTO, Kyrgyzstan being a developing country engaged into commitments of developed countries that also negatively affected the trade balance.

This paper is based on quantitative analysis by using statistics of Organization for Economic Co-operation and Development (OECD), World Resources Institute (WRI), Food and Agriculture Organization Statistics (FAOSTAT), National Statistics Committee of Kyrgyz Republic, Ministry of Economic Regulation and Trade of Kyrgyz Republic, Ministry of Agriculture of Kyrgyz Republic.

Books and websites also have been used in conducting the research. Empirical analysis has been conducted by Pearson Correlation Method (SPSS). 


\section{Biases in the Trading System Against Developing Countries}

As a large share of trade flows has been intraregional and intra-firm, efforts by developing countries to participate fully in an increasingly interdependent global economy have been hindered by biases in the trading system (Report of the Secretary-General of UN, 2001).

According to the principle of comparative advantage, a country gains from trade when it specializes in areas of production or processing where it is relatively more competitive.

Food and Agriculture Organization (FAO) studies show that this principle is severely violated by a number of obstacles that work mostly against the interests of developing countries. Agriculture remains one of the most highly protected arenas of international trade. Tariffs average around $4 \%$ for industrial goods but $62 \%$ on agricultural products. (Thomas C. Beierle 2002,5). Governments, particularly in rich developed countries, also continue to subsidize domestic farmers in ways that

substantially distort trade by favoring domestic production and exports over imports from abroad. Market distortions caused by subsidies, tariffs and technical barriers to trade, discourage farmers in developing countries from being competitive.

For a large number of developing countries, especially the 82 low-income food-deficit countries (LIFDCs) currently identified by FAO, the agricultural sector remains largely underdeveloped, in respect of production both for the domestic market and for export. At the same time, in most of these countries, the agricultural sector lies at the centre of their economies. It accounts for a large share of GDP, employs a large proportion of the labor force, represents a major source of foreign exchange earnings, supplies the bulk of basic food required by the population and provides subsistence and other income for large rural populations. It provides a living for more than $50 \%$ of developing countries' population, on average. In developed countries, only around $9 \%$ of the population lives off agriculture (FAO 2009, 12-14).

The WTO agreements, which were the outcome of the 1986-1994 Uruguay Round of trade negotiations, provide numerous opportunities for developing countries to make gains. Further liberalization through the Doha Development Agenda negotiations aims to improve the opportunities.

But a number of problems remain. The poorest group of developing countries, the G90 has placed on the Doha Agenda a number of problems they face in implementing the present agreements. And they complain that they still face exceptionally high tariffs on selected products ("tariff peaks") in important markets that continue to obstruct their important exports. A related issue is "tariff escalation", where an importing country protects its processing or manufacturing industry by setting lower duties on imports of raw materials and components, and higher duties on finished products.

Although some of the developing countries have increased their share in world exports of processed agricultural products, the developed countries captured the bulk of the rapidly growing trade in this sector. High dependence on exports of primary agricultural products continued to be a prominent feature in many developing countries, particularly the least developed countries (LDCs). The share of developing countries in world exports of processed agricultural products decreased from 27 percent in 1981-1990 to 25 percent in 1991-2000. For LDCs as a group, the share in processed agricultural exports fell sharply from 0.7 percent to 0.3 percent (FAOSTAT 2003).

\begin{tabular}{|c|c|c|c|c|c|c|}
\hline \multirow{2}{*}{ years } & \multicolumn{3}{|c|}{ Primary products } & \multicolumn{3}{c|}{ Processed products } \\
\cline { 2 - 7 } & Developed & Developing & LDCs & Developed & Developing & LDCs \\
\hline $1981-1990$ & 62.2 & 33.8 & 3.1 & 73.0 & 27 & 0.7 \\
\hline $1991-2000$ & 67.4 & 32.6 & 2.2 & 75.0 & 25 & 0.3 \\
\hline
\end{tabular}

Table 1. Share in world agricultural exports, all commodities (\%)

According to FAO today, the share of developing countries in world food trade adds up to about 27 percent of total - essentially the same level as 20 years ago.

\subsection{Global consequences of developed country domestic support}

Domestic support to farmers of developed countries leads to unequal outcomes at the expense of developing countries.

Although developed countries in Doha Development Round of the WTO have agreed to eliminate export subsidies by 2013, the EU and U.S. and Japan are unwilling to make significant concessions on domestic support ( EarthTrends 2007). 


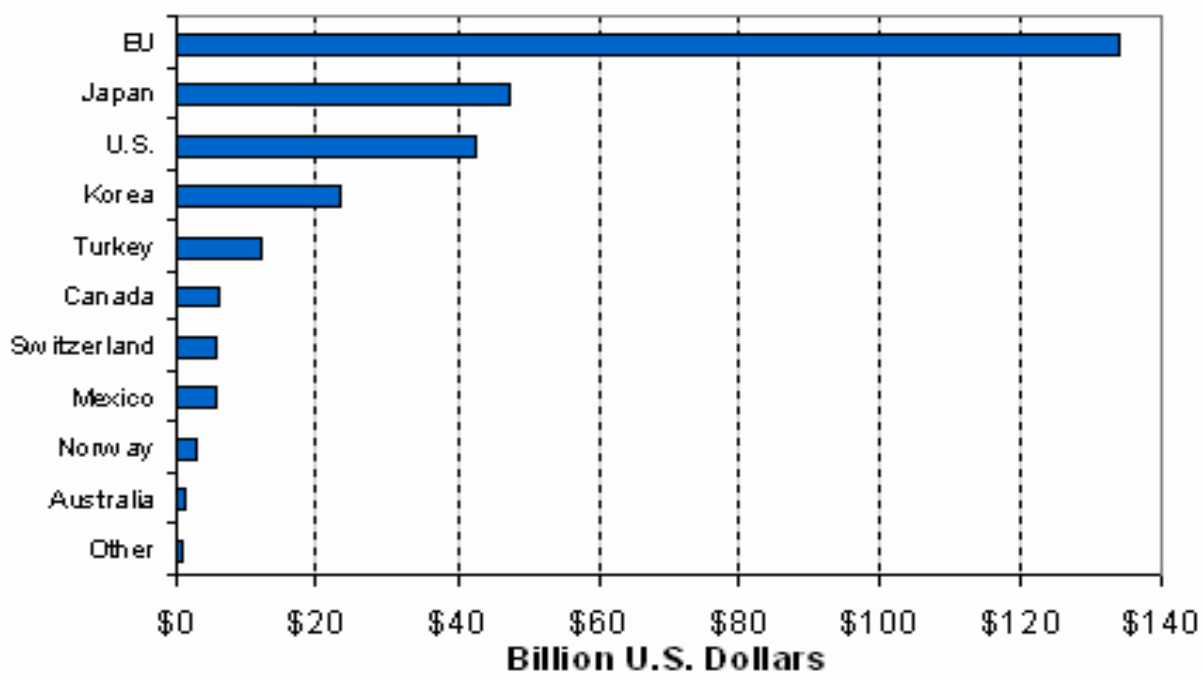

Figure 1: Domestic Support to Farmers

The agricultural subsidies and tariffs used by wealthy countries to support their farming sectors as having a serious, if not fatal, drag effect on the sustainable development of agriculture in the poor parts of the world. The U.S. Department of Agriculture (USDA) calculates that protectionist policies in developed countries are responsible for around $80 \%$ of global agricultural price distortions, with the European Union contributing 38\% and the United States around 16\%. These policies raise commodity prices domestically but depress them on world markets by about $12 \%$ on average (Thomas C. Beierle 2002,p9).

Domestic support to agriculture in developed countries encourages over-production, which in turn increases supplies on world markets (by reducing import demand or increasing export supply) and depresses world prices. Low prices make it harder for producers in developing countries to compete in their home markets, as well as in international markets, thus reducing incentives for production and retarding the development of the agricultural sector.

\subsection{Import surges in developing countries}

As a result of domestic support of developed countries many developing countries are vulnerable to import surges (temporary sharp rises in imports) and temporary low import prices that could damage agricultural production activities. Import surges and low import prices are of particular concern to developing countries striving to develop agricultural potential and diversify production to enhance food security and alleviate poverty. While lower import prices may benefit consumers, sudden and large temporary declines in commodity level prices disproportionately hurt producers.

\begin{tabular}{|c|c|c|}
\hline \multicolumn{2}{|c|}{ Developing countries(DC) } & Developed countries \\
\hline All DCs & LDCs & \\
\hline 5.6 & 5.2 & 1.9 \\
\hline
\end{tabular}

Table 2. Growth rate trend of food imports (percent per annum, 1990-2000)

Since the 1990s, food imports by developing countries have been rising sharply: 5.6 percent per annum for developing countries and by 6.9 percent for the LIFDCs (FAO 2003). Projections indicate that this trend will continue.

\subsection{Internal supply constraints}

Many developing countries, particularly LDCs, face internal supply constraints that limit their ability to respond to opportunities for trade in processed agricultural products. These include weak technology; insufficient transport, storage and marketing infrastructure; inadequate legal and regulatory arrangements; and policyinduced disadvantages resulting from trade and macroeconomic policies that are biased against agriculture and exports.

\section{Impact of WTO on Kyrgyzstan's trade}

\subsection{Kyrgyzstan's trade conditions before entering the WTO}

The major peculiarity of external economic integration of Kyrgyzstan lies in participation of Kyrgyzstan in many international and regional organizations. Before entering the WTO Kyrgyzstan became a member of Custom union (Russia, Kazakhstan, Belarus, Tadjikistan), in 2000 a member of Eurasian Economic Community. However a creation of CU wasn't effective. Very slow process of harmonization of tariffs and legislation 
influenced international trade. Adopted tariffs of CU members were different. Complexity of harmonization process was linked with ineffective work of regulative institutions which coordinated the sphere of external trade and production. Another problem of economic integration is that governmental trade agreements were directed to regulative trade that prevented development of market mechanism.

\begin{tabular}{|c|c|c|c|c|c|}
\hline (billionsUS dollars) & $\mathbf{1 9 9 4}$ & $\mathbf{1 9 9 5}$ & $\mathbf{1 9 9 6}$ & $\mathbf{1 9 9 7}$ & $\mathbf{1 9 9 8}$ \\
\hline Trade turnover & 657.1 & 9312 & 1343.1 & 1313.1 & 1355.1 \\
\hline Export & 340.1 & 408.9 & 505.4 & 603.8 & 513.6 \\
\hline Import & 317 & 522.3 & 837.7 & 709.3 & 841.5 \\
\hline Trade balance & +23.1 & -113.4 & -332.3 & -105.5 & -327.9 \\
\hline
\end{tabular}

Table 3. Dynamics of external trade of Kyrgyzstan in period proceeding entry in WTO

Despite the fact that in period from 1994 to 1998 years external trade turnover of the republic doubled, the balance of trade was negative and increased annually. From 1996 external trade turnover growth rate decreased substantially (National Statistic Committee of Kyrgyzstan 2010). The major problem of integration within CU countries was economic recession of all former Soviet states in that period. In such conditions any international activities objectively couldn't have neither political nor economical results.

Search for external factors that could positively affect the internal production process, and also willingness to declare itself as a new independent government contributed to the decision of Kyrgyzstan to enter the WTO.

The entrance of Kyrgyzstan the WTO assumed the establishment of stable tariff regimes that would give the government competitive advantage over other CU members.

Also there were many political and economical premises of entering the WTO. The major political reasons of entering the WTO are protection and support by more developed countries. In order to have equal relationships with foreign partners the republic should have to be under the protection of international law.

The primary economical premises of entering the WTO are a provision of privileges for export of goods and services in the market of WTO member countries. Also by entering the WTO Kyrgyzstan supposed to get more stable and predictable conditions for investments that could lead to increase of volume and improvement of quality of investments in all sectors of the economy.

\subsection{The major trade partners of Kyrgyzstan with WTO member countries}

The major trade partners of Kyrgyzstan in WTO are the countries of European Union (external trade with them amounts 23.1\%), China (23\%), USA (10\%), Turkey (6,3\%) (Brovko N.A 2010, p62).

However, Kyrgyzstan doesn't have stable trade relationships with most WTO member countries. In different years export and import indices increase or decrease sharply.

Only with one WTO member country- Switzerland, Kyrgyzstan has positive trade balance. In the last five years more than $90 \%$ of export to Switzerland was due to the export of gold. Dynamics of import goods from Switzerland increased by 1.8 times from 2002 to 2006, mainly because of medical and pharmaceutical products. Kyrgyzstan has relatively stable tendency in trade with China and Turkey (Brovko N.A 2010, p 62).

Kyrgyzstan exports to Turkey leather and wool materials. China is interested in import of scraps, copper, aluminum and aluminum withdrawals from Kyrgyzstan.

Despite the constant growth of total import volume from China there is no steady volume of imported goods that complicates specification of leading import goods from China.

In comparison with China import from Turkey for the last five years there is a stable specification of import groups such as equipment, plastic and plastic goods, finished food stuffs, alcoholic and non-alcoholic beverages and tobacco, clothes and construction materials.

\subsection{Trade condition of Kyrgyzstan with WTO countries and EurAsEC.}

From 2004 trade turnover with WTO countries is decreasing (National Statistic Committee of Kyrgyzstan 2010).

\begin{tabular}{|c|c|c|c|c|c|c|c|}
\hline & $\mathbf{2 0 0 2}$ & $\mathbf{2 0 0 3}$ & $\mathbf{2 0 0 4}$ & $\mathbf{2 0 0 5}$ & $\mathbf{2 0 0 6}$ & $\mathbf{2 0 0 7}$ & $\mathbf{2 0 0 8}$ \\
\hline Trade turnover & 100 & 100 & 100 & 100 & 100 & 100 & 100 \\
\hline WTO & 52.9 & 40.1 & 47.2 & 43.2 & 41.9 & 37.3 & 31.2 \\
\hline
\end{tabular}

Table 4. Kyrgyzstan's total external trade turnover ratio with WTO member countries(\%)

The major reasons of turnover decrease are:

1. weak internal market and low level of standard of life in Kyrgyzstan

2. territorial remoteness of Kyrgyzstan from major members of WTO

3. imperfection of export structure and it's raw material orientation 
From the table below it is clear that in comparison to trade with WTO member countries export and import with EurAsEC member countries is increasing steadily. Kyrgyzstan mainly trades with Russia and Kazakhstan. $44 \%$ of Kyrgyzstan's total trade turnover amounts only with those two countries (Russia 26, 9\%, Kazakhstan 16, 8\%) (National Statistic Committee of Kyrgyzstan 2010).

The increase of export volume is explained by the fact that Kyrgyzstan imports from WTO countries and then re-exports imported goods to EurAsEC. (mainly to Russia and Kazakhstan)

\begin{tabular}{|c|r|r|r|r|r|r|}
\hline & \multicolumn{1}{|c|}{$\mathbf{2 0 0 2}$} & \multicolumn{1}{|c|}{$\mathbf{2 0 0 3}$} & \multicolumn{1}{c|}{$\mathbf{2 0 0 4}$} & \multicolumn{1}{c|}{$\mathbf{2 0 0 5}$} & \multicolumn{1}{c|}{$\mathbf{2 0 0 6}$} & \multicolumn{1}{c|}{$\mathbf{2 0 0 7}$} \\
\hline EurAsEC & 377.6 & 530.5 & 752.2 & 837.2 & 1307.7 & 1987.7 \\
\hline Export & 128.4 & 174.5 & 249.1 & 274.8 & 369.1 & 554.4 \\
\hline Import & 249.2 & 356 & 503.1 & 562.4 & 938.6 & 1433.3 \\
\hline Trade balance & -120.8 & -181.5 & -254 & -287.6 & -569.5 & -879.9 \\
\hline WTO & 567.4 & 673.3 & 783.1 & 766.3 & 1052.5 & 1326.2 \\
\hline Export & 307.3 & 371.6 & 430.7 & 351.8 & 333.2 & 437.7 \\
\hline Import & 260.1 & 301.7 & 352.4 & 414.5 & 719.3 & 888.5 \\
\hline Trade balance & +47.2 & +69.9 & +78.3 & -62.7 & -386.1 & -450.8 \\
\hline
\end{tabular}

Table 5. Kyrgyzstan's trade with WTO countries and EurAsEC (millions of US \$)

\subsection{Empirical analysis of Kyrgyzstan's import dependence within WTO}

As well as other developing countries within WTO, Kyrgyzstan became strongly dependent on import. The results were that a correlation between GDP and import is $96 \%$, which means that interrelation between GDP and import is very significant. (Table6). Figure 2 illustrates that sharp rise of import since 2005 reflect a parallel growth of GDP. At the same time, export has been dependent on import (a correlation between export and import is $87 \%$ ). Export growth is explained by existence of re-export, as Kyrgyzstan imports goods at law tariff from WTO members (especially from China and Turkey) and re-exports them to its regional trade partners.

\begin{tabular}{|c|c|c|c|c|}
\hline & & import & export & GDP \\
\hline import & Pearson Correlation & 1 & $\mathbf{, 8 7 7 ^ { * * }}$ & $\mathbf{, 9 6 7}^{\text {*** }}$ \\
& Sig. (2-tailed) & &, 000 &, 000 \\
& $\mathrm{~N}$ & 14 & 14 & 14 \\
\hline \multirow{2}{*}{ export } & Pearson Correlation &, $877^{* *}$ & 1 & $\mathbf{, 8 8 2}^{* *}$ \\
& Sig. (2-tailed) &, 000 & &, 000 \\
& $\mathrm{~N}$ & 14 & 14 & 14 \\
\hline GDP & Pearson Correlation &, $967^{* *}$ &, $882^{* *}$ & 1 \\
& Sig. (2-tailed) &, 000 &, 000 & 14 \\
\hline
\end{tabular}

Table 6: Correlations between import, export and GDP. ${ }^{* \star}$ Correlation is significant at the 0.01 level (2-tailed).

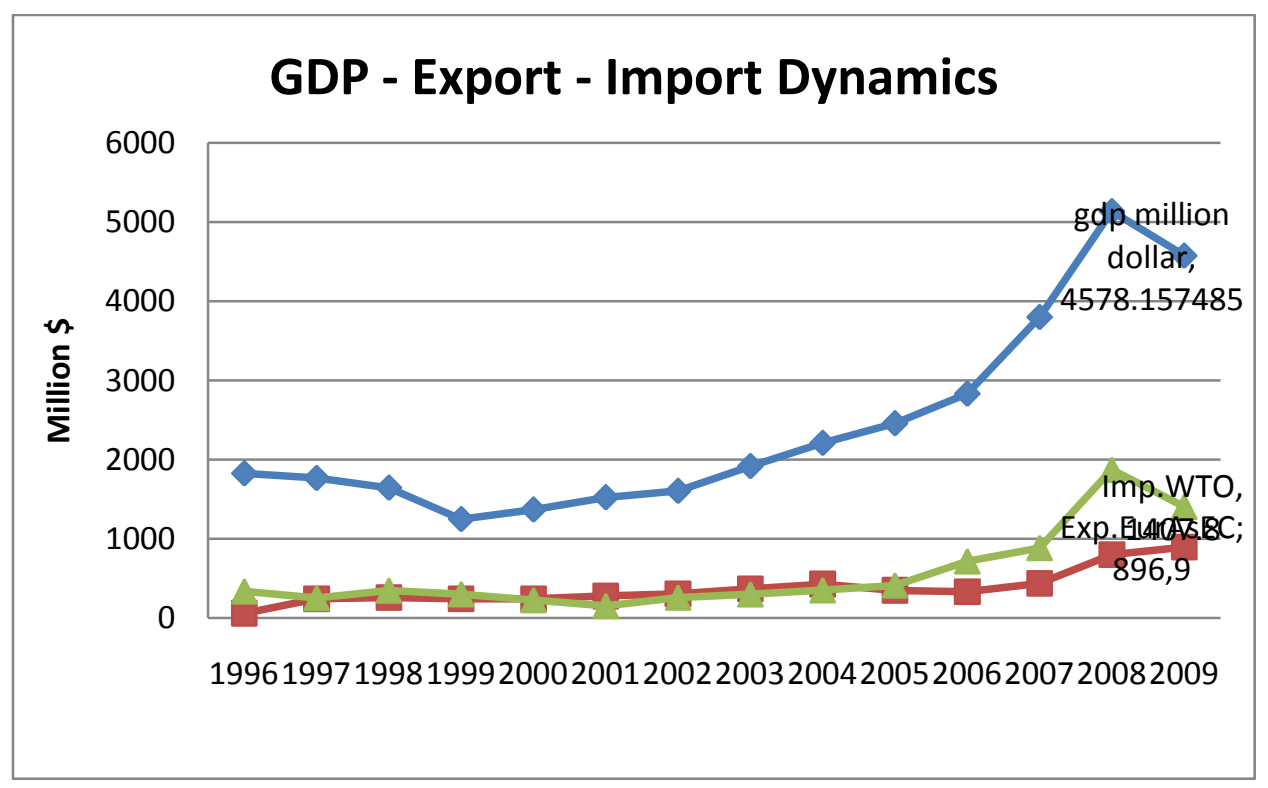

Figure 2: GDP - Export - Import Dynamics 


\section{Custom Union and Kyrgyzstan}

The formation of the Custom Union between Russia, Belarus and Kazakhstan influences economy of Kyrgyzstan mainly trade flows, revenues generated by imports, consumer price levels and employment. While most effects would result from Kyrgyzstan's joining the CU, the mere existence of the CU has some important effects even if Kyrgyzstan remains outside - in particular on the substantial transit trade in Chinese goods that has developed in recent years.

\subsection{Major Impacts from Joining the Custom Union.}

- Adopting the Common External Tariff (CET) in its present state would roughly double the average tariff applied by Kyrgyzstan, from an average of $5.1 \%$ to the CET average of $10.6 \%$.

- The accession of Kyrgyzstan to the Customs Union would be a remarkable step towards integrating economic relations with Russia and the other CU members and would significantly reduce trade relations with non- CIS states.

- Because budget revenues in Kyrgyzstan are heavily dependent on import duties and VAT collected on imports, reduced imports from non-CIS countries have the potential to significantly reduce state revenues, despite the fact that average tariff for non-CIS imports would be approximately doubled. Kyrgyzstan's reliance on revenues from imports contrasts with Russia's and Kazakhstan's reliance on export revenues.

- Adoption of the CU CET would be a major change. Approximately 92\% of the Common External Tariff (CET) is based on the Russian tariff, which is focused on protection of Russian producers from imports and encouragement of transition of consumers of other CU countries to Russian products. This is a tariff designed to benefit Russia.

- Adoption of the CU CET would result in an increase in consumer prices. Prices for goods imported from CU members would not change, but those for goods from non-CIS countries would increase markedly.

- The accession of Kyrgyz Republic to the CU will decrease GDP of Kyrgyzstan.

- The accession of Kyrgyzstan to the CU will result in huge inflow processed goods from Kazakhstan and Russia. Currently the presence of such goods is already at high level. Customs opening will influence to domestic producers. Exporting primary products producers will lose a revenue generation from value added.

- Kyrgyzstan under GATT Art. XXVIII have to offer a "compensatory adjustment" to WTO members if it enters to the CU. It can amount from 1, 5-7 billions of US dollars.

- The CU will broaden the market size which will attract the FDI inflow; investors are interested in investing not in one certain country but in a regional union.

- Kyrgyz agricultural goods and construction materials are more competitive than Chinese goods, as China is not a member of Custom Union and it is imposed with higher tariffs. Thus Kyrgyz goods have a potential to be exported in to the Custom Union members.

- The closure of customs will lead to the rise of prices to agricultural products giving the incentive for Kyrgyz farmers to produce more goods with higher quality and volume.

Moreover, the differences among the economic indices of the current CU members and Kyrgyzstan are enormous ( Allen M. Shinn, Askar Beshimov and Azamat Usubaliev 2010). So the gain of Kyrgyzstan in trading with CU members will be significantly less in comparison with other members.

\begin{tabular}{|c|c|c|c|c|}
\hline $\mathbf{2 0 0 8}$ & Kyrgyzstan & Belarus & Kazakhstan & Russia \\
\hline GDP, billion USD & 5.0 & 60.3 & 135.6 & 1676.6 \\
\hline Agriculture & $26 \%$ & $9 \%$ & $6 \%$ & $6 \%$ \\
\hline Industry & $17 \%$ & $39 \%$ & $42 \%$ & $39 \%$ \\
\hline Services & $57 \%$ & $53 \%$ & $52 \%$ & $54 \%$ \\
\hline GDP growth & $7.6 \%$ & $10.0 \%$ & $3.3 \%$ & $5.6 \%$ \\
\hline $\begin{array}{c}\text { GDP per capita, thousand } \\
\text { USD }\end{array}$ & 0.95 & 6.23 & 8.72 & 11.81 \\
\hline $\begin{array}{c}\text { Export, } \% \text { of GDP } \\
\text { Import, } \% \text { of GDP }\end{array}$ & $61 \%$ & $54 \%$ & $61 \%$ & $28 \%$ \\
\hline $\begin{array}{c}\text { Postal money transfers and } \\
\text { compensations, billion USD }\end{array}$ & 1.23 & 0.45 & 0.19 & $17 \%$ \\
\hline Inflation, GDP deflator & $26 \%$ & $16 \%$ & $21 \%$ & $18 \%$ \\
\hline Population, million people & 5.3 & 9.7 & 15.6 & 142 \\
\hline Population growth, $\%$ & $1.1 \%$ & $-0.2 \%$ & $0.1 \%$ & $-0.1 \%$ \\
\hline
\end{tabular}

Table 3: Data of the CU members and Kyrgyzstan 
These data demonstrate that the economy of Kyrgyzstan is a great deal smaller than the economies of the other members. GDP per capita is much lower, agriculture and international trade are much more important, and population growth is higher. The dominating position of Russia is obvious. These differences immediately suggest that CU conditions that favor the much more highly developed Russian economy may well not favor the very different situation in Kyrgyzstan. All three CU members have much higher levels of industrial development than

Kyrgyzstan, and all three have much less dependence on agriculture. Russia and Kazakhstan depend heavily on commodity exports. Russia and Belarus have large but relatively inefficient industrial sectors, which require protectionist tariffs in order to survive international competition. Russia and Kazakhstan are significant markets for Kyrgyz products and important sources of Kyrgyz imports, particularly fuel. Kyrgyz trade with Belarus, however, is insignificant.

Thus, it is clear that entering the CU is not economically beneficial for Kyrgyzstan. Even if Kyrgyzstan has a big trade turnover with Russia and Kazakhstan there is no proper trade policy with those countries. It is necessary to define all possible risks and expected outcomes of joining the CU.

\section{Conclusion}

Major focus of this paper is based on analysis of condition of developing countries in agriculture within WTO, impact of WTO membership on Kyrgyzstan's trade. After conducting the research certain consequences of developing countries membership in WTO became evident. The cost of agricultural protection falls particularly hard on developing countries, where agriculture typically accounts for a much higher share of economic output, exports, and employment than in developed countries. Agricultural sector growth is critical to many developing countries' overall economic growth, and reform of protectionist policies promises many billions of dollars of annual benefits to developing countries as a whole. The second issue of developing countries is that they became strongly dependent on import. Thus, building appropriate trade negotiations with WTO members is crucial for developing countries.

They should achieve fairness on tariff setting in agriculture and production sectors.

Despite the fact that Kyrgyzstan's experience in WTO has not been efficient, it should not consider the accession to the Custom Union as the best alternative because the research analysis show that entering the CU is not economically beneficial for Kyrgyzstan. Also, there is no appropriate trade policy, which could represent efficient and stable trade relations with CU countries. It is necessary to attract re-exporters into the production sector. Even if the time of re-export is used up, it is impossible abruptly to change the system. It is better for Kyrgyzstan to wait until CU members enter the WTO because last negotiations of Russia and Kazakhstan with WTO members show that their accession will be completed in near future. By that time Kyrgyzstan should develop its agriculture and production sector.

\section{References}

- Dictionary of trade policy terms 2nd ed. 1998,187

- Report of the Secretary-General of UN, 2001. "Finance and trade". "Trade and Development and the Department of Economic and Social Affairs of the United Nations", 30 April- 2 May 2001

- $\quad$ FAOSTAT (2003)

- $\quad$ EarthTrends 2007, using data from OECD 2006

- Agricultural Trade Reform and Poverty in the Developing World, April 2007.

- http://earthtrends.wri.org/updates/node/194

- Allen M. Shinn, Askar Beshimov, Azamat Usubaliev. April 19, 2010. Economic Consequences of the Customs Union for the Kyrgyz Republic

- National Statistic Committee of Kyrgyzstan 2010 